\title{
Scintiphotosplenoportography による門脈循環の研究
} （第 4 報） ${ }^{133} \mathrm{Xe}$ による肝血流量測定

\begin{tabular}{|c|c|c|}
\hline 柏木 & 杼田 & 武信* \\
\hline 末松 俊彦* & 阿部 & 裕* \\
\hline
\end{tabular}

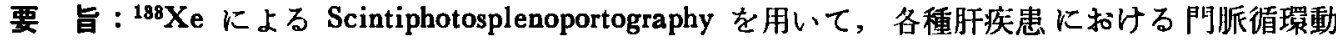
態の検討ならびに局所肝組織血流量の測定を行った，慢性肝炎13例中 1 例，肝硬变症17例中10例 に肝外短絡血流路，肝硬変症 2 例に肝内短絡血流路の存在を恝めた．局所肝組織血流量の測定で は, 朋硬変症群において肝疾患のない群や慢性肝炎群に比し朋右葉の血流量の明らかな低下が認 められたか，肝左葉に関しては有意差を認めなかった．右葉と左葉の組織血流量は必ずしも均一 ではなく右葉高値の場合が多く，肝硬変症群にては左葉高値例も存在した．しかもこれら局所肝 組織血流量ならびにその肺内分布は常に一定ではなく変動しやすいと考えられた．
\end{abstract}

索引用語：経皮脾門脈造影法門脈循壊 肝䛻環 肝血流量 ${ }^{189} \mathrm{Xe}$ 組織りリアランス法

はじめに

肝疾患における門脈ならびに肝循環動態の究明は，肝 疾患の病態を理解するうえに，さらには肝疾患患者の診 断, 予後判定, 治療方針決定に極めて重要な指針を与え ると考えられる。

我ふは肝血行動態研究の一環として ${ }^{99} \mathrm{~m} \mathrm{TcO}_{4}$-による 経皮脾門脤造影法である Scintiphotosplenoportography （SSP）を開発し，臨床的に梗めて有用な方法であること

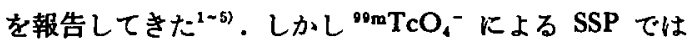
肝血流量までる测定することが不可能であるため，最近 諸摑器の血流量測定に使用されている ${ }^{133} \mathrm{Xe}$ を脾内 に注入し， ${ }^{133} \mathrm{Xe} に よ る \mathrm{SSP}$ 開発しだ．今回本法 により肝疾患に和ける門脈循環動態の検討ならびに肝右 葉と左葉の局所肝血流量の測定を行ったので報告する。

\section{対象および方法}

对象恰阪大病院に入院した患者34例で，男性22例，女 性12例, 年龄は23〜72歳である. 症例の内訳は Table 1 に示した. No. 2 と 3 の症例は, 腹胿鏡, 開復所見によ りそれぞれ肝に異常がないことが確かめられており， No. 4 以下の症例では肝組耭所見によって猃断を確定し

\footnotetext{
* 大阪大学 第 1 内科

** 大阪大学 中央故射線部

*** 大阪大学 第 2 外科
}

〈受付日51年 6 月 25 日 $>$
た.

方法は，患者を少なくとも8時間以上絶食させたらえ 仰卧位としシンチカメラ（日䇋メディコ社製）を上腹部 にほほ密着させ，23Gのカテラン針にて経皮的に脾内へ $2 \mathrm{ml}$ 以下の ${ }^{193} \mathrm{Xe}$ 生食液 ( $\left.5 \sim 15 \mathrm{mCi}\right)$ を注入した。 RI イメージはシンチカメラと on line system で直結 したデータ処理装䈯を用いて脾注後 1 秒每120秒まで磁 気テープに転送記録した，後に再生しまず RI イメー ジから肝外短絡血流路の有無を検討した。つぎに Fig. 1 に示すごとく肝の右葉と左葉に関心領域を設定しこれれ らの領域に批る ${ }^{133} \mathrm{Xe} の$ washout curve を得た。大部 分の washout curve で Fig. 1にみられるよらな plateau な時期が，脾注後30〜40秒をで存在したため，消失倸数 ๘は，40秒以後の 対数变換された washout curve の勾 配を最小自乗法によって計算しさらに60を乗じて求め た. 肝血流量 (HBF) は, この $\boldsymbol{\kappa}$ 值を用いて次式优従っ て算出した。

$$
\mathrm{HBF}=\frac{100 \cdot \kappa \cdot \lambda}{\rho}(\mathrm{ml} / 100 \mathrm{~g} / \mathrm{min})
$$

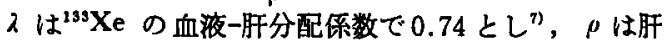
比重で1.02としだ．また右葉と左葉の血流量の比較の ために各症例で右葉と左葉の血流量の比を計算した。

No. 14〜18の 5 症例では, ${ }^{193} \mathrm{Xe} の$ 肝における radioactivity が十分瑊少した 30 分後に再度 ${ }^{133}$ Xe の脾注を行 った，No. 34の症例に対しては，肝癌か疑われたため肝 
Table 1. Results of regional hepatic blood flow and shunt detection by scintiphotosplenoportography using ${ }^{133} \mathrm{Xe}$

\begin{tabular}{|c|c|c|c|c|c|c|c|c|c|}
\hline \multirow[t]{2}{*}{ Case } & \multirow[t]{2}{*}{ Sex } & \multirow[t]{2}{*}{ Age } & \multirow[t]{2}{*}{ Diagnosis } & \multicolumn{2}{|c|}{$\mathrm{K}^{* 1}(/ \mathrm{min})$} & \multicolumn{2}{|c|}{$\begin{array}{l}\text { Hepatic Lobar Flow } \\
(\mathrm{m} l / 100 \mathrm{gm} / \mathrm{min})\end{array}$} & \multirow[t]{2}{*}{$\mathrm{R} / \mathrm{L}^{* 4}$} & \multirow[t]{2}{*}{ Shunt } \\
\hline & & & & Right L.*22 & Left L.*3 & Right L. & Left L. & & \\
\hline 1 & $\mathbf{F}$ & 55 & Polycythemia vera & 1.276 & 0.690 & 92.6 & 50.1 & 1.85 & - \\
\hline 2 & $\mathbf{M}$ & 72 & Cholecystopathy & 1.346 & & 97.7 & & & - \\
\hline 3 & $\mathbf{M}$ & 48 & Gastric cancer & 0.941 & 0.529 & 68.3 & 38.4 & 1.78 & - \\
\hline 4 & F & 23 & Chronic hepatitis & 0.943 & 0.700 & 68.4 & 50.5 & 1.35 & - \\
\hline 5 & $\mathbf{M}$ & 58 & Chronic hepatitis & 1.143 & 1.033 & 82.9 & 74.9 & 1.11 & - \\
\hline 6 & $\mathbf{M}$ & 35 & Chronic hepatitis & 1.082 & 0.917 & 78.5 & 66.5 & 1.18 & 一 \\
\hline 7 & $\mathbf{M}$ & 50 & Chronic hepatitis & 0.847 & 0.717 & 61.4 & 52.0 & 1.18 & - \\
\hline 8 & $\mathbf{M}$ & 25 & Chronic hepatitis & 1.168 & 0.875 & 84.7 & 63.5 & 1.33 & - \\
\hline 9 & $\mathbf{F}$ & 39 & Chronic hepatitis & 1.547 & 0.808 & 112.2 & 58.6 & 1.91 & - \\
\hline 10 & $\mathbf{M}$ & 49 & Chronic hepatitis & 0.939 & 0.854 & 68.1 & 62.0 & 1.10 & - \\
\hline 11 & $\mathbf{F}$ & 34 & Chronic hepatitis & 0.881 & 0.593 & 63.9 & 43.0 & 1.49 & - \\
\hline 12 & $\mathbf{F}$ & 24 & Chronic hepatitis & 0.913 & 0.633 & 66.2 & 45.9 & 1.44 & - \\
\hline 13 & F & 39 & Chronic hepatitis & 0.994 & 0.828 & 72.1 & 60.1 & 1.20 & + \\
\hline \multirow[t]{2}{*}{14} & $F$ & 29 & Chronic hepatitis & 1.024 & 0.959 & 74.3 & 69.6 & 1.07 & - \\
\hline & & & & 1.103 & 0.803 & 80.0 & 58.3 & 1.37 & - \\
\hline \multirow[t]{2}{*}{15} & $\mathbf{F}$ & 45 & Chronic hepatitis & 0.954 & 0.727 & 69.2 & 52.7 & 1.31 & - \\
\hline & & & & 0.762 & 0.734 & 55.3 & 53.3 & 1.04 & 一 \\
\hline \multirow[t]{2}{*}{16} & $\mathbf{M}$ & 45 & Chronic hepatitis & 1.042 & 0.996 & 75.6 & 72.3 & 1.05 & - \\
\hline & & & & 1.101 & 0.874 & 79.8 & 63.4 & 1.26 & - \\
\hline \multirow[t]{2}{*}{17} & $\mathbf{M}$ & 55 & Liver cirrhosis & 0.529 & 0.354 & 38.4 & 25.7 & 1.49 & + \\
\hline & & & & 0.481 & 0.472 & 34.9 & 34.2 & 1.02 & + \\
\hline \multirow[t]{2}{*}{18} & $\mathbf{M}$ & 54 & Liver cirrhosis & 1.045 & 0.688 & 75.8 & 49.9 & 1.52 & + \\
\hline & & & & 0.776 & 0.612 & 56.3 & 44.4 & 1.27 & + \\
\hline 19 & $\mathbf{M}$ & 37 & Liver cirrhosis & 0.659 & 0.626 & 47.8 & 45.4 & 1.05 & - \\
\hline 20 & $\mathbf{M}$ & 23 & Liver cirrhosis & 1.145 & 0.960 & 83.1 & 69.6 & 1.19 & + \\
\hline 21 & $\mathbf{M}$ & 54 & Liver cirrhosis & 0.625 & 0.480 & 45.3 & 34.8 & 1.30 & + \\
\hline 22 & $\mathbf{F}$ & 38 & Liver cirrhosis & 0.969 & 0.911 & 70.3 & 66.1 & 1.06 & - \\
\hline 23 & $\mathbf{M}$ & 40 & Liver cirrhosis & 0.613 & 0.572 & 44.5 & 41.5 & 1.07 & + \\
\hline 24 & $\mathbf{M}$ & 37 & Liver cirrhosis & 0.372 & 0.496 & 27.0 & 36.0 & 0.75 & + \\
\hline 25 & $\mathbf{F}$ & 66 & Liver cirrhosis & 1.084 & 0.768 & 78.6 & 55.7 & 1.41 & - \\
\hline 26 & $\mathbf{M}$ & 47 & Liver cirrhosis & 0.583 & & 42.3 & & & + \\
\hline 27 & $\mathbf{M}$ & 57 & Liver cirrhosis & 0.455 & 0.407 & 33.0 & 29.5 & 1.12 & $+^{* 5}$ \\
\hline 28 & $\mathbf{M}$ & 54 & Liver cirrhosis & 0.687 & 0.642 & 49.8 & 46.6 & 1.07 & $t^{* s}$ \\
\hline 29 & F & 65 & Liver cirrhosis & 0.420 & 0.415 & 30.5 & 30.1 & 1.01 & + \\
\hline 30 & $\mathbf{M}$ & 24 & Liver cirrhosis & 0.960 & 1.078 & 69.7 & 78.2 & 0.89 & + \\
\hline 31 & $\mathbf{M}$ & 43 & Liver cirrhosis & 1.050 & 1.134 & 76.2 & 82.3 & 0.93 & - \\
\hline 32 & $\mathbf{F}$ & 53 & Liver cirrhosis & 0.367 & 0.299 & 26.6 & 21.7 & 1.23 & + \\
\hline 33 & $\mathbf{M}$ & 51 & Liver cirrhosis & 0.834 & 0.415 & 60.5 & 30.1 & 2.01 & - \\
\hline \multirow[t]{2}{*}{34} & $\mathbf{M}$ & 52 & Fatty liver & 0.563 & 0.351 & & & 1.60 & - \\
\hline & & & & $0.522^{* 6}$ & $0.382^{* 6}$ & & & 1.37 & \\
\hline
\end{tabular}



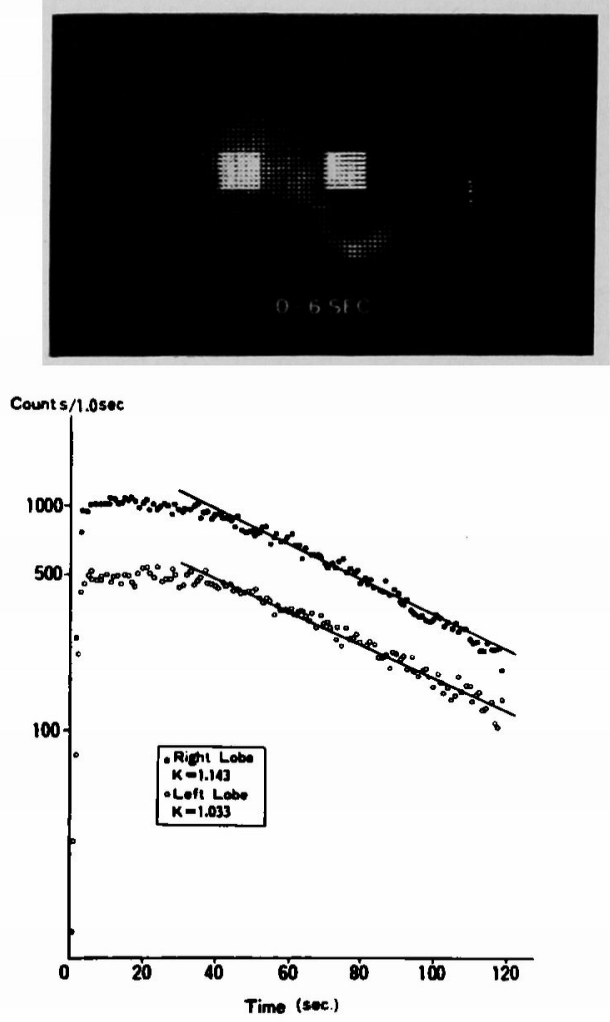

Fig. 1 Chronic hepatitis (no. 5). After an injection of ${ }^{133} \mathrm{Xe}$ into the spleen, zero to $6 \mathrm{sec}$ digital scintiphotograph (upper panel) shows the splenic and portal veins and liver clearly. Areas of interest were set over the right and left hepatic lobes for washout studies. Lower panel shows logarithmic washout curves over the both areas of the liver.

動脈造影を施行し，その際カテーテルを通じて ${ }^{133} \mathrm{Xe} の$ 肝動脈内注入を行い, 引続き胿内注入を行った。

\section{成 縝}

${ }^{199} \mathrm{Xe}$ による SSP においてる Fig. 1〜3 にみられる ごとく脾静脈, 門脈, 肝, さらに肝外短絡血流路の明膫 なイメージかえられた。 そして慢性肝炎13例中 1 例, 肝 硬変症17例中10例に肝外短絡血流路の存在を認めた．

肝に扰ける ${ }^{19}{ }^{9} \mathrm{Xe} の$ washout curve は, 通常 Fig. 1 にみられるごとく初期の30〜 40秒間 plateauな時期を有 し, 以後 monoexponential に下降したが, 肝外短絡血流 路を有する例では肝左葉の washout curve は, Fig. 2 K みられるごとく初期に peak を形成する場合か，しばし ばみられた．一方肝硬变症の 2 例 (No. 27と28) では,

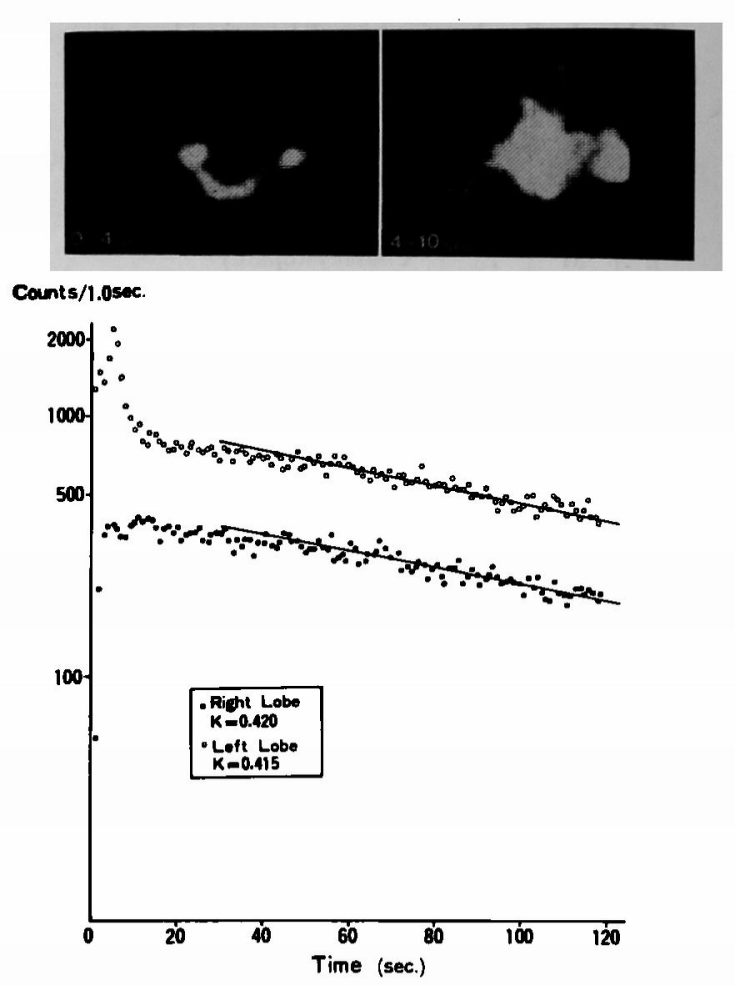

Fig. 2 Liver cirrhosis (no. 29). Four to $10 \mathrm{sec}$ scintiphotograph (upper right) shows the portosystemic collateral channels clearly. The washout curve over the left lobe (lower panel) indicates a sharp initial hump emanating from the portosystemic collateral channels.

肝右葉の washout curve は，Fig. 3にみられるよらに初 期から下降し, 肝内短絡血流路の存在を示唆した。

各症例における肝右葉ならびに左葉の $几$ 値, 肝組織血 流量,肝右葉と左葉の血流量比, 肝内外短絡血流路の有無 をTable 1 に示した．肝右葉ならびに左葉の組織血流量 は，Fig. 4 に示すごとくそれぞれ肝疾患のない群86.2士 $12.8,44.3 \pm 5.9 \mathrm{~m} l / 100 \mathrm{~g} / \mathrm{min}$, 慢性肝炎群75.1土13.0, $58.6 \pm 8.9 \mathrm{ml} / 100 \mathrm{~g} / \mathrm{min}$, 朋硬変群 $52.2 \pm 18.3,46.6 \pm$ $18.2 \mathrm{ml} / 100 \mathrm{~g} / \mathrm{min}$ であり, 所硬変群の右葉の 血流量は 肝疾患のない群と $\mathrm{P}<0.02 て ゙$, 慢性肝炎群 とは $\mathrm{P}<$ 0.01で明らかな低下が認められた。しかし左葉の血流量 では, 慢性肝炎群と肝便変群との間に有意差がみられな かった。

肝右葉と左葉の組織血流量比は, 0.75〜2.01で,比較の ため 1.11 以上を右葉優浆例， $1.10 \sim 0.91$ を均等例, 0.90 以下を左葉倛勢例とした場合，肝疾患のない群では 2 例 

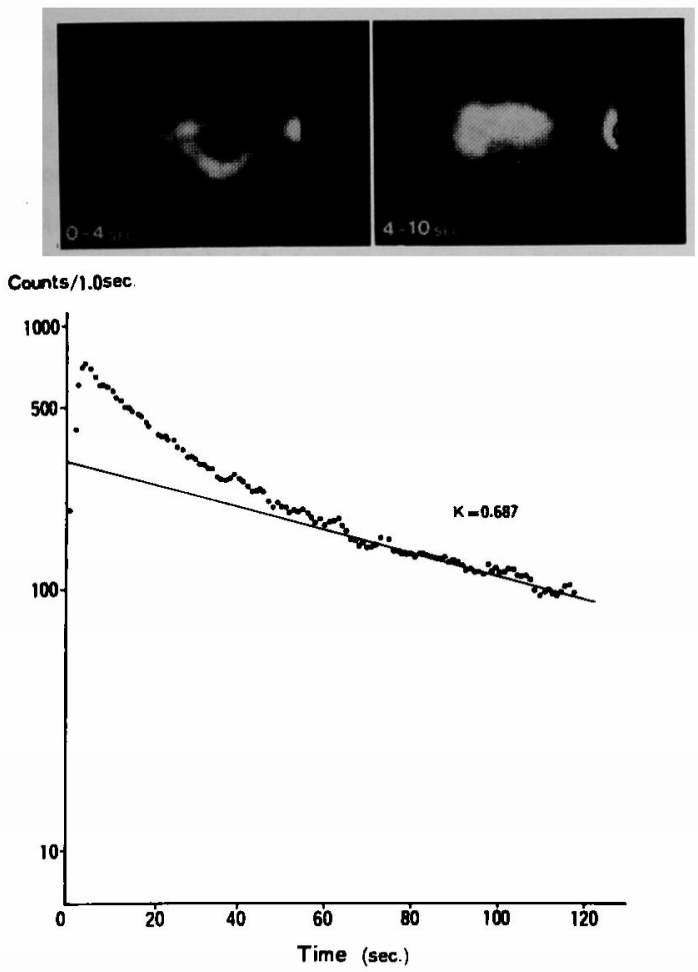

Fig. 3 Liver cirrhosis (no. 28). Scintiphotographs (upper panel) suggest the absence of portosystemic collateral channels. The washout curve over the right lobe (lower panel) indicates the rapid fall from the beginning, suggesting the presence of intrahepatic shunts.

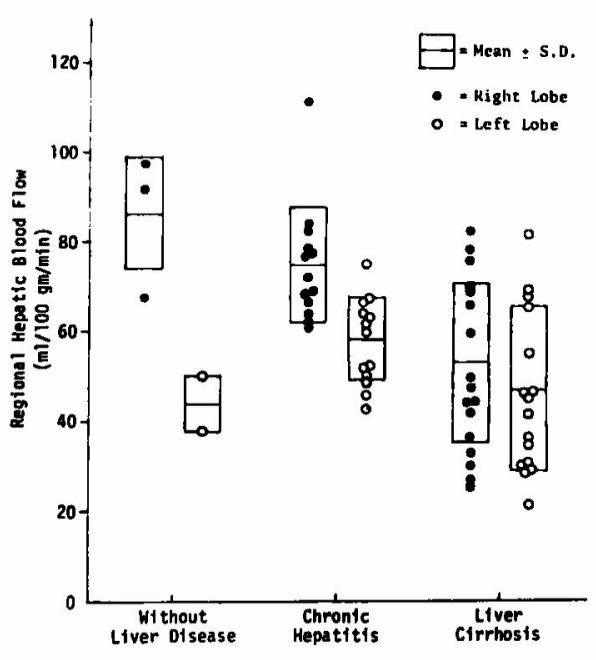

Fig. 4 Right and left lobar flow values for patients without liver disease, with chronic hepatitis and with liver cirrhosis.
中 2 例が右葉僂勢, 慢性肝炎群では13例中12例が右葉優 教, 1 例が均等, 肝硬変群では16例中 8 例が右葉優勢, 6 例が约等，2 例が左葉传熒を示した。なお同一症例で 2 回測定を行った場合, 疾患群の比較には平均值をその 怔例の值とした. No. 34 の症例は脂肪肝であったため， 消失係数の算出のみで，血流量の棓算は行わなかった。

\section{考案}

放射性不活性ガスである ${ }^{133} \mathrm{Xe}$ あるいは ${ }^{85} \mathbf{K r}$ は， 脂溶性のため血液一組織分配俰数にしたがって容易に組 織に扗散し，1回肺を通過すると95\%以上が呼気中へ排 出されるといら特改を有している，したがって不活性か スの組織への再循環はほとんどなく、組織に払散した不 活性ガスはその組織に流入してくる血流量に依存して組 織から washout されるため, 組織からのの不活性ガスの 堿"!゙を計測して組䄉血流量を求めるのが，不活性ガス組 織クリアランス法による血流测定法である.この方法に

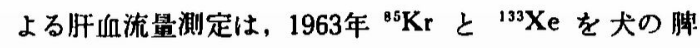
静脈および脾内に注入して測定した Iio らの報告”には しまり, 翌年 Reesらが犬の肝動脈扰よび門脈に注入した 成績影を,そして1965年にはUeda らが脾内注入によると トでの応用 ${ }^{10)}$ 発表している，以後動物においてては肝動 脈および門脈内注入法 ${ }^{11-13)}$ あるいは肝実質内直接注入 法 ${ }^{14}$ による成績が報告され，ヒトでる肝実質内直接注入 法 $^{15,16)}$ や肝静脈カテーデルによる肝実質への注入法 ${ }^{17}$,

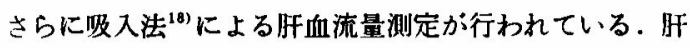
血流量測定法として不活性ガス組織クリアランス法の有 する特徵は，従来の BSP, ICG あるいは放射性 colloid による方法とことなり肝実質細胞機能と無関保に血流量 が测定できることであり，またこの方法によって得られ た肝血流量は肝組織を栄盖する血流量であるため肝の機 能遂行上むっとも有効な 血流量が測定できることであ る.

我々はこの様な優れた特改を有する放射性不活性ガス 組織クリフランス法を SSP に応用し ${ }^{13} \mathrm{Xe}$ によるSSP を開発した．この方法では門脈循環動態の異常を視覚的 また動的に知ることができるのみならず，局所肝組織血 流量の测定が行え, 测定時間は 2 分間と短くかつ ${ }^{139} \mathrm{Xe}$ の肝からの消失は速やかであるため反復測定す可能であ る.しかむ測定は体外計测であるため採血を全く必要と しない.また ${ }^{133} \mathrm{Xe}$ の脾内への注入量は $1 \sim 2 \mathrm{ml}$ と少 量であり，注入に祭して麻酔等の処圈を要しないため生 理的に近い状態での血流動態を知ることができると考え られる。 
$20: 752$

肝に括ける ${ }^{133} \mathrm{Xe} の$ washout curve は通常初期の30〜 40秒間 plateau る.この plateau な時期が存在する理由は明確ではない が，同様の所見は cat の門脈内に直接 ${ }^{133} \mathrm{Xe}$ を注入し たDarle の実験 ${ }^{19}$ でるみられ，plateau な時期にはだ ん肝組織に拡散する ${ }^{133} \mathrm{Xe}$ と肝組織から washoutされ る ${ }^{133} \mathrm{Xe}$ が関心領域内で平衡状態になっているのであ ろらと思われる.しかし plateauな時期がみられない症 例む少数例ながら存在し，その中で Scintiphotosplenoportogram で肝外短絡血流路が みられ，かつ肝左葉の curve のみ初期から下降する場合は肝外短絡血流路を通 過する ${ }^{133} \mathrm{Xe}$ の radioactivity の影響と考えられる。一 方肝外短絡血流路と重ならない肝右葉において curve か 初期から下降する場合は, 組織に拡散せす速やかに肝内 を通過する ${ }^{133} \mathrm{Xe}$ が存在することを示唆して括り，こ れは肝内短絡血流路の存在を示すと考えられる。したが っ ${ }^{133} \mathrm{Xe} に よ る$ SSP は肝内短絡血流路の診断にも有 用と思加る。

${ }^{139} \mathrm{Xe}$ によるSSP は，すでに述へてをたよらにいく つかの優れた利点を有しているが, 反面問題点がないわ けではない。 ${ }^{133} \mathrm{Xe}$ を用いて組織クリアランス法により 肝血流量を計算するには ${ }^{133} \mathrm{Xe} の$ 肝よりの消失係数 $\kappa$ と ともに血液一肔分配係数入と肝比重 $\rho$ を知る必要がある. とくに入は，肝の脂肪含量によって影響を受けるので， 肝の脂肪含量が変化しやすい肝疾患では個々の症例の２. が異なっていることが想像される．しかしヒトのれゃ を测定することが現時点では不可能なため我ふは犬での 值 $\left(\lambda=0.74^{7)}, \rho=1.02^{3)}\right)$ を用いかつ一定として血流 量の計算を行った。そして肝疾患で組織学的に脂肪変性 の認められた症例は，No. 34の症例を除いて対象から除 外した，最近この問題の解決策として脂溶性の罢なる2 核種（たとえば ${ }^{85} \mathrm{Kr}$ と ${ }^{133} \mathrm{Xe} ）$ を用いる方法 ${ }^{17,18)}$ が報 告されており，今後検討を要すると思われる，そのほか この方法では不活性ガスの注入経路が問題になる.肝動 脈血流と門脈血流は sinusoid で混和していると現在考 えられているため, 肝動脈, 門脈いずれの経路から不活 性ガスを注入しても測定された組織血流量の值は同一に なるはずである。しかるに実際動物で測定された成績で は肝動脈注入の場合が門脈注入の場合よりる低值になる

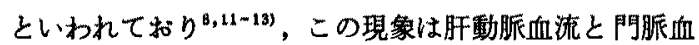
流の functional separation によると説明されている。こ の点に関してヒトではいまだ不明であり，我々が肝癌の 疑われた脂肪肝の 1 例に肝動脈注入法と脾内注入法を連
17 巻10号 (1976)

続して行ってえた成績では，䀒動脈注入法による肝右葉 の $\boldsymbol{\kappa}$ 值は，脾内注入法に比し若干低值を示したが，肝左 葉のに值は逆後者の方が高值を示した。従ってヒト で動物と異なり肝動脈血流と門脈血流の functional separation が存在しないのかるしれないしかしいずれ にせよ門脈注入法によって得られた血流量か，他の方法 によって測定された肝血流量とよく一致するとされてい るため ${ }^{8,13)}$ ，門脈注入法とほぼ同様と考えられる脾内注 入法によって得られた我々の測定值は，一応肝組織血流 量とみなして差支えないと思われる。

近年核医学に括けるシンチカメラとそれに付随する データ処理装置の開発は, RI イメージとともに radioactivity の 経時的変化を追跡する dynamic study を可

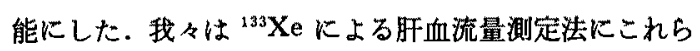
の装眉を用いて，門脈循環動態の観察とともに従来の方 法では困難であった肝右葉ならびに左葉の局所肝血流量 の測定を行った．その結果肝右葉の組織血流量は, 肝疾 患のない群揾性肝炎群に比し䀒硬变群では明らかに低 下していることが認められたが，肝左葉に関しては疾患 群の間に明らかな差が認められなかった。一方同一症例 に和ける右葉と左葉の血流量を比較すると, 肝疾患のな い群や慢性肝炎群で㤌右葉優勢例が多く, 肝硬变群にな ると右葉優勢例が減少して均等例が増加し, さらに左葉 優勢例が出現する傾向がみられた。これらの成績から推 測すると，七トの肝炡に打ける組織血流量の分布は均一 ではなく，とくに右葉の組織血流量が左葉に比し高值な 状態が多く，肝硬変症になると右葉の血流量が低下し， その割に左葉の血流量はあまり変化を受けず相対的に組 織血流量として左葉優勢の状態が出現し，さらに進行す ると左藮の血流量も低下するのかむしれない：このよう な肝組織血流量の変化から考鼻ると肝硬変症の肝シンチ グラムにみられる肝右葉萎縮左葉腫大などの種々の形態 変化る一応理解できるように思われる。また肝矣患のな い群が少数例のため正常肝に打ける組織血流分布にまで 言及することは問題があるが，正常肝にてる右葉の組蟣 血流量が左葉に比し豊富と考えると胎生初期に左右差の なかった肝葉が次第に対称性を失い左葉の発育が遈くな ることや、左葉が右葉に比し萎縮しやすいこと淂，さらに は従来門脈流線現象によるとされてきたてメー：性肝滕 䭲や胞虫塞腫の右葉頻発を説明できるように思われる。 しかし逆に何故左葉に比し右葉の組織血流量が滈值であ るかを説明することは容易ではない。これには肝右葉に 流入する右門脈主枝は太く短く，左葉に流入する左主枝 
は門派本幹に対して直角に横走し右枝よりも細く長いと い5門脈走行上の差が関与しているのかもしれない。

我ふは肝両葉に批け血流の分布差が存在したため 5 症例に反復測定を行い，その变動を検討したところ Table 1にみられるごとく多少の変動を認めた。これは 測定法そのものに由来する可能性を全く否定できない、 が，それよりはむしろすでに報告した門脈流線現象と同 様 ${ }^{3,5)}$, 局所肝組織血流量およびその肝内分布状態が変 動しやすいことる示していると考えられる。るして No. 18の症例を除く他の 4 症例における局所旰組筻血流量 は，一方が減少すれば他方が增加する傾向を有してお り，肝組織血流量全体としてはたいして変動していない

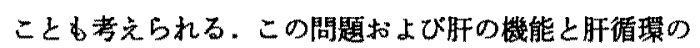
関保を解明するには局所肝組織血流量のみならず全肝組 織血流量の測定が是非とも必要と考えられるが,これを 求めるには肝容積の測定が不可欠であり, 今後生体にお ける肝容積測定法の確立が望まれる。

\section{結語}

1) ${ }^{133} \mathrm{Xe}$ による SSP は肝血行動態検査法として以 下の点について優れていると考えられる。

(1) 門脈循環動態と肝血流量といら肝疾患の診断, 予 後の判定に極めて重要な2つの情報を短時間に容易かつ 安全にしかる同時に得ることができる.

(2) 肝の機能遂行上最む重要な肝組織を栄盖する血流 量が得られる。

(3)肝内短絡血流路の讋断が可能である。

2）肝右葉ならびに左葉の組織血流量は，肝疾患のな い群 $86.2 \pm 12.8,44.3 \pm 5.9 \mathrm{ml} / 100 \mathrm{~g} / \mathrm{min}$, 慢性肝资群 $75.1 \pm 13.0,58.6 \pm 8.9 \mathrm{~m} l / 100 \mathrm{~g} / \mathrm{min}$, 肝硬変群 $52.2 \pm$ $18.3,46.6 \pm 18.2 \mathrm{ml} / 100 \mathrm{~g} / \mathrm{min}$ で, 肝硬变群の肝右葉 の血流量は，他の群に此し明らかに低下していた。しか し肝左葉の血流量に関して各群に有意差が誌められなか った.

3）肝内に括ける組綫血流量の分布は必ずしも均一で はなく，右葉传努の場合が多く肝硬变群になると均一群 が増加し左葉優智例る出現した。

4）肝組織血流量ならびにその肝内分布は常に一定で はなく, 変動しやすい.

\section{文部}

1)柏木 徹他: Scintiphotosplenoportography によ る門脈循環の研究 (第 1 報) ${ }^{00 \mathrm{~m}} \mathrm{TcO}_{4}$ - による 門脈系血管造影. 肝缄, $14: 537,1973$.

2）柏木 微他 : Scintiphotosplenoportography によ
る門脈循環の研究 (第 2 報) 門脈血流速度扣よ び脾肝循環時間の測定. 肝䑏, $15: 149,1974$.

3）柏木 徽他 : Scintiphotosplenoportography によ 万門脈循環の研究（第 3 報）門脈流線現象の検 討. 肝腀, $15: 310,1974$.

4) Kashiwagi, T. et al.: Dynamic studies on the portal hemodynamics by scintiphotosplenoportography: the visualization of portal venous system using ${ }^{\mathrm{m}} \mathrm{Tc}$. Gastroenterology, 67: $668,1974$.

5) Kashiwagi, T. et al.: Dynamic studies on the portal hemodynamics by scintiphotosplenoportography: streamline flow in the human portal vein. Gastroenterology, 69: 1292, 1975.

6)柏木 微他： Scintiphotosplenoportography に よる肝血流量湘定．医学のあゆみ，95:320， 1975.

7) Conn, H.L.: Equilibrium distribution of radioxenon in tissue: xenon-hemoglobin association curve. J. Appl. Physiol., 16: 1065, 1961.

8) Rees, J.R. et al.: Hepatic blood flow measurement with xenon 133. Lancet, 2: 562, 1964.

9) Iio, M. et al.: Radioactive krypton and xenon in the measurement of coronary, hepatic, and cerebral blood flow. J. Nucl. Med., 4: 213, 1963.

10) Ueda, H. et al.: Detection of portal systemic shunts by hepatopulmonary scanning using I $^{131}$ MAA. Jap. Heart J., 6: 115, 1965.

11) Hollenberg, M. \& Dougherty, J. : Liver blood flow measured by portal venous and hepatic arterial routes with $\mathrm{Kr}^{85}$. Am. J. Physiol., 210: 926, 1966.

12) Birtch, A.G. et al.: Hepatic blood flow measured by the krypton- 85 clearance technique. Surgery, 62: 174, 1967.

13) Darle, N.: ${ }^{133}$ Xenon-uptake, clearance and liver blood flow. An experimental study in the cat. Acta Chir. Scand., 136 Suppl. 407, 1970.

14) Hall, C. et al.: Wash-out of intraparenchmally injected xenon-133 as a parameter of liver blood flow in the dog. Scand. J. Clin. Lab. 
Invest., 35: 635, 1975.

15) Gelin, L.E. et al.: Liver blood flow in man during abdominal surgery. Acta Hepatosplenol., 1: 13, 1968.

16）暒田明義他：門脈循環のラジオアイソトープ検 查一 ${ }^{033} \mathrm{Xe}$ による局所肝血流測定一, 日本臨床, $27: 541,1969$.

17) Lundbergh, P. \& Strandell, T.: Hepatic wash-out curves of ${ }^{85} \mathrm{Kr}$ and ${ }^{133} \mathrm{Xe}$ after retro- grade hepatic venous injections in patients with infectious hepatitis and in controls. Scand. J. Clin. Lab. Invest., 33: 277, 1974.

18) Schmitz-Feuerhake, I. et al.: Determination of the specific blood flow of the liver by inhalation of radioactive rare gases. Acta HepatoGastroenterol., 22: 150, 1975.

19) Benz, E.J. et al.: Atrophy of the left lobe of the liver. Arch. Path., 53: 315, 1952.

Studies on the portal circulation by scintiphotosplenoportography: measurement of regional hepatic blood flow with ${ }^{133} \mathrm{Xe}$ in man

\author{
Toru Kashiwagi*'**, Takenobu Kamada*, Kazufumi Kimura*'**, \\ Toshihiko Suematu*, Hiroshi AbF* and Kazuhiro Okagawa***
}

The technique of scintiphotosplenoportography permits visualization of portal venous system and estimation of regional hepatic blood flow by injecting ${ }^{139} \mathrm{Xe}$ into the spleen. This technique is easily, rapidly and repeatedly performed. Portosystemic collateral channels were detected in 1 of 13 patients with chronic hepatitis and 10 of 17 patients with liver cirrhosis. In 2 cirrhotic patients intrahepatic shunts were detected.

Measurement of regional hepatic blood flow in right and/or left lobes was performed in 33 patients. The right and left lobar flows were $86.2 \pm 12.8,44.3 \pm 5.9 \mathrm{ml} / 100 \mathrm{~g} / \mathrm{min}$ in 3 patients without liver disease, $75.1 \pm 13.0,58.6 \pm 8.9 \mathrm{ml} / 100 \mathrm{~g} / \mathrm{min}$ in 13 patients with chronic hepatitis and $52.2 \pm 18.3,46.6 \pm 18.2 \mathrm{ml} / 100 \mathrm{~g} / \mathrm{min}$ in 17 patients with liver cirrhosis respectively. These results suggest that heterogeneity of flow in right and left lobes exists and in patients with liver cirrhosis right lobar flow is significantly decreased.

* First Department of Medicine, Osaka University Medical School (Osaka)

** Department of Radiology and Nuclear Medicine, Osaka University Medical School

*** Second Department of Surgery, Osaka University Medical School 